\title{
Araquistain en el teatro
}

20.12. L lado de Azorin, de José Ortega y Gasset, de Ramiro de Maeztu, de Gómez de Baquero y varios otros escritores, Luis Araquistain es uno de los intelectuales españoles de más fornida contextura y más viril fisonomía.

Cerebro enriquecido por una cultura sölida y variada. Araquistain ha vivido en una permanente actividad trabajadora, ofreciendo sin descanso a las prensas artículos y libros de la más diferente condición espiritual.

Es verdaderamente admirable la labor de este esforzado caballero de la pluma. Los más distintos temas han sido objefo de su examen y de sus comentarios; pero en el dilatado conjunto de su obra no se podrian advertir inconsecuencias ni divisar contradicciones. La extensa diversidad de sus tareas exterioriza en la común orientación de los valores, una visible y consistente columna vertebral.

Critico, novelador y periodista, este escritor no ha podido, con todo, circunscribir su acción a la revista y al volumen. Su dinamismo cerebral es tan intenso y desbordante, que ha debido buscar el camino más directo para llegar a los demás, y ha llevado su pensamiento y su sapiencia al oleaje del teatro. No conforme con la forzosa e impasible frialdad de la palabra impresa, ha querido que sus reflexiones y sus inquietudes tomen las formas vivas y ardorosas del diálogo dramático.

Habria fundamento para creer que su primera concepción escénica, estrenada en el Español de Madrid el 21 de Marzo de 1923. fuera algo endeble y balbuciente, toda vez que el teatro es un secreto que no se entrega de una manera lácil; pero no 
es asi. Remedios heroicos es una pieza de maciza envergadura, pieza que acusa en el artifice un conocimiento no pequeño de los resorles teatrales.

Pocos han entrado con paso más seguro que Luis Araquistain en el terreno resbaladizo del arte de Aristófanes. Remedios heroicos, en tres actos y en prosa, no parece el primer documento de un autor de teatro, sino el producto lógico de una experiencia prolongada en esta clase de faenas.

Es aquel un drama sobrio, aunque recargado de lintas; un borbotón humano que no podia haber inspirado sino el genio de Ibsen, aquel hombre nebuloso y austero que vivió escudriñando el misterio de las almas.

El mismo Araquistain decia: eYo me complazco en reconocer aqui mi gran deuda a lbsen, y sin èl Remedios heroicos es probable que no hubiera existido nunca o, en todo caso. en forma muy distinta. Siempre me ha parecido pueril negar u ocultar las influencias que colaboran a la formación de la propia personalidad.,

Araquistain ha llegado, pues, al teatro conducido de la mano por el filósofo noruego. No podia haberse presentado mejor acompañado. Y como la de Ibsen, es la suya labor de auscultación y de sondeamiento, labor 'de disección y raciocinio, labor de análisis y critica. trabajo de inventario y de severa cirugia.

Remedios heroicos rompe moldes y destroza tradiciones en el nombre del progreso indefinido de la sociedad y de la especie. Según una opinión, es el drama de la clibertad individuals. La protagonista, sacudiendo cadenas ancestrales, arrojando la coyunda sacramental del matrimonio, se rebela contra ella, contra sus imposiciones rigidas y consuetudinarias, y se entrega al instinto de la maternidad, dando expansión al ejercicio de un derecho perfectamente natural.

Podrán ser controvertibles las ideas fundamentales de esfe drama de Luis Araquistain: podrán ser resistidas y duramente condenadas; podrán merecer desdenes y reproches-chocan ellas contra lo establecido y consagrado-: pero no podrá ser discutida ni negada la buena fe del dramaturgo y su ensueño fer- 
voroso de perfeccionamiento humano bajo las banderas de la libertad individual.

Todos estos problemas, complejos y abismales, no podrán tener nunca soluciones de aceptación unánime. Cada fórmula de desenlace habrá de conlar indefectiblemente con partidarios y con opositores: pero en cualquiera solución que se planlee, hay que aplaudir el anhelo de progreso social que la ha determinado, la inclinación a corregir anomalias retardatarias o nocivas y el propósito de abrir a la corriente de la vida senderos de grandeza y horizontes luminosos.

$\mathrm{Y}$ esto es lo que hace más plausible que todo el hondo drama de Luis Araquistain y con ello, el valor con que encara el problema y el afán de arrastrar la caravana de los hombres hacia planos mejores. hacia un ambiente en que todo individuo pueda vivir sin reticencias sus instintos superiores $y$ sus derechos permanentes.

Como es de suponerlo, Remedios heroicos resonó cual una aguda clarinada de batalla. La prensa de Madrid comentó extensamente sus premisas y sus sugestiones, y todos los criticos estuvieron acordes en reconocer los méritos del drama. El de -La Voz, decia: - Remedios heroicos es, en nuestro concepto. la obra de más fuerza ideológica estrenada de varios años a esta parte., y el critico de .El Liberal. afirmaba que tal obra presentaba a Araquistain somo una gloriosa realidad de autor dramático, al que seguramente deberemos en no escasa medida $y$ en no lejano plazo. el resurgimiento del featro nacional, hoy desmayado y envilecido, salvo contadisimas excepciones, en manos lan torpes como pecadoras.

A Araquistain no envanecieron los aplausos, ni ellos le hicieron, por supuesto, desviar su trayectoria. Cualquiera otro habria aprovechado la disposición favorable del público para haberla explotado en beneficio personal. Pero Luis Araquistain no podia dar fines mezquinos a su insigne apostolado.

Durante el año 1924 laboró tranquilamente y sólo el 19 de Mayo de 1925 llevó a las tablas su segunda producción, El rodeo, estrenada en la Latina por Maria Palou. 
La influencia de Ibsen sigue evidenciándose, tanto en los procedimientos como en los personajes. De este modo se explica que la crilica opinara en el sentido de que la heroina. ecelosa y mujer. tendiendo cautelosamente la trampa de sus ficciones. dando un rodeo atrevido, jugando en el envite su propia vida para descubrir el fondo de las almas de su marido y de su hermana, tiene la altura de una Hedda Gablers.

Como debía serlo. el drama es áspero y lóbrego, un envolvente torbellino de sombras; una negra espiral de tragedia con toda la desesperada y convulsiva rudeza de una lucha sin posible avenimiento.

La presencia de Ibsen está en El rodeo llenando sus escenas de intensidad y de tristeza: derramando colores opacos; destejiendo en el diálogo palabras temblorosas, palpitantes de amarguras y repletas de sollozos.

Grande y robusta es la figura de la protagonisla y los diversos sentimientos que pasan por su pecho dan un relieve extraordinario a su personalidad. Ella, su marido y su hermana vienen a ser los tres pilares en que se edifica el drama. Los tres, unidos por lazos de lalalidad, por vinculos de odio. de amor y de egoísmo, son seres que la vida ha de entregar a la vorágine, al choque y a la muerte, porque ¿de qué manera podria resolverse aquel combale ciego por la posesión de un hombre. en que actúan, salidos de cauce, los impulsos de la carne y las pasiones más violentas?

Aquellos personajes están cogidos por la garra de un destino inexorable y tenebroso que los hace inferiores a la espantosa fortaleza de los empujes en acción.

La fatalidad asoma su cabeza en este drama y maneja las figuras, sin que éslas puedan eludirla ni acierten a sobreponerse. Según el mismo Araquistain, las criaturas de esta obra eno son como vulgarmente se dice, ni malas ni buenas; son sencillamente trágicas, obedientes por ineludible necesidad a la ley de su propia vida, a su más profunda ley moral, y leales a todas sus consecuencias, .

Los personajes de El rodeo siguen la ruta trazada por su 
naturaleza psicológica, sin torcer a la presión de intereses ajenos y sin temor al vilipendio de la tradición o la rutina.

El drama ha sido desenvuelto con loda su crudeza, desnudamente, con un valor y una franqueza que excluyen eufemismos y no admiten circunloquios. La frase es ácida, resuelta, quemante. tal como lo requiere la candente vibración del asunto y la violencia del momento.

El rodeo es un drama de creciente tormenta, hasta que finaliza deshecho en una fiera y luctuosa borrasca pasional.

Y cuando todavia no se borraba la impresión de aquel drama, el 14 de Diciembre de 1925 estrenaba el maestro otra obra, El coloso de arcilla.

Este drama continúa reflejando por entero a Araquislain en sus modos de pensar y construir. Lo importante en esta obra es su fondo y a él sacrifica el arlifice los elementos puramente teatrules.

La critica tachó en este drama lo abarcante del tema y lo elevado de los vuelos, cosas que impidieron que su contenido y su belleza llegaran fácilmente hasla todas las conciencias y en ellas arrancaran las debidas resonancias.

Segün el crítico de .El Liberal, de Madrid, pretende Araquistain demostrar que la actual civilización, pese a todas sus apariencias de solidez y de grandeza. es cosa deleznable y en peligro de pulverizarse si la Humanidad no atiende a lo lundamental, dando de lado, a costa de todos los dolores y de lodas las renunciaciones, a lo accesorio, y da forma a su propósito de demostrarlo por medio de corporificaciones de un carácter emblemático.

En El coloso de arcilla cada personaje es un simbolo y por esta circunstancia el tercer drama de Luis Araquistain no será del todo accesible para públicos siempre acostumbrados a tipos de otro orden.

Pero, a pesar de todo, en esta obra afirma Araquistain su personalidad de autor dramático y se coloca en condiciones de ocupar una plaza expectable en la vanguardia de quienes per- 
petúan, remozándolo, el esplendor inmarcesible del teatro castellano.

La pericia de Luis Araquistain está ya suficientemente probada en el terreno de la literatura escénica. Acaso podría reprochársele que no tiene un completo dominio de la técnica; pero hay que convenir en que él sólo se obtiene merced al ejercicio de una práctica constante. Es que también la opulencia mental de Araquistain, sus elevadas ascensiones y su excesiva honradez ideológica, lo alejan de los convencionalismos y de los artificios que requiere la composición dramática. Asi su featro ha resultado algo escueto y esquemático, algo demasiado rectilineo, pero sincero como pocos.

Las piezas de Luis Araquistain han debido, sin duda, extrañar a públicos habituados a un teatro de habilidades mecánicas y de recursos exteriores, a un teatro en que todo está dispuesto para agradar al auditorio.

Araquistain no se somete de lleno a las exigencias de la forma ni sacrifica a ella la integridad del pensamiento ni la esencia de la idea. Su punto de vista y su concepto filosófico no sufren menoscabo al pasar a la obra de teatro. No persigue el dramaturgo aplausos fáciles ni triunfos precipitados. Expone sus teorias $\sin$ transigir ni claudicar.

El público no preocupa a Araquistain como a los otros comediógrafos. Escribe absolutamente de acuerdo con él mismo. Por eso ha sido motejado muchas veces de poco comprensible. Habla en no pocas oportunidades desde una esfera superior a la de sus oyentes, y no todos pueden seguir de una manera fácil el caminar de su razonamiento ni llegar hasta el fondo de los valores que elucida.

Se advierte que Araquistain no piensa al escribir en deslumbrar ni en promover admiración. Sólo desea convencer, y de ahi que la fuerza de su obra gravite por entero en la idea, en la entraña sustantiva, en la materia medular.

Su labor se singulariza por su acentuada propensión a exponer sin timideces sus pareceres éticos y sus apreciaciones sociológicas, sin recurrir al efectismo literario ni a los resortes deci- 
sivos del calor y el movimiento. Esta circunstancia indica que Araquistain no adula a nadie ni persigue los favores del vulgo - la rutina. Sus dramas van teñidos con la sangre de su espiritu y llevan el sello de esa unción y probidad que sólo puede dar a su tarea el que va tras resultados de verdad y de progreso.

Semejante característica hará simpático al teatro de Araquistain para todos, aun para aquellos que están en plano opuesto y en total antagonismo con sus apreciaciones. Lo que molesta es lo anodino. lo incoloro, lo hipócrila.

El teatro del autor de El rodeo puede anolar a su favor el hecho no generalizado de haber sido escrito sin concesiones a temores de ninguna especie. Combate francamente situaciones consagradas, abandonando las cómodas y habituales posiciones de casi todos los dramálicos. Es aquel un teatro sin vistas a la taquilla ni a la popularidad.

La producción de Araquistain ha debido causar extrañeza por esta circunstancia, ya que está confeccionada sin seguir las corrienles impuestas por antiguas costumbres y sin tratar de satisfacer ni de servir los gustos artísticos ni las inclinaciones élicas de la mayoría.

Al revés de los demás autores, Araquistain anhela que el auditorio piense con el autor y que colabore con él. Sólo asi. según el dramaturgo, podría el público fundirse con el aulor y el autor alcanzar su deseo de fundirse con el público. Para Araquistain únicamente de este modo es posible alcanzar una obra sólida donde se integren el artista y el espectador..

Un teatro asi no será, sin duda alguna, el preferido por un público que fiene el hảbito de no colaborar; por un público no acostumbrado a las actividades mentales y que va al teatro a ser un simple receptáculo de imágenes y frases: por un público, que en su mayor parle, sólo persigue las recreaciones del color, la caricia del vocablo, el cosquilleo del retruécano.

Pero Araquistain no va tras las preferencias-caprichosas y tornadizas-de los espectadores. Va a la escena a discurrir. a plantear problemas, a destruir preocupaciones, a señalar nuevos 
trayectos, a extirpar todo aquello, que a su juicio, pone alguna barrera al desarrollo sano y conveniente de la familia universal. Luis Araquistain es, ante todo, un pensador que se disfraza de dramático, buscando campos más abiertos y fecundos a sus ansias sembradoras.

Afrontando dificultades y venciendo resistencias, Araquistain entrega al surco la semilla de su idea. Por la sonora bocina del teatro deja caer sín miedo sus grandes convicciones y sus vastas esperanzas. Podrán ser sus creencias discutibles, erróneas y hasta perjudiciales en el sentir de mucha gente; pero de todos modos, hay que admirar en Luis Araquistain al hombre valeroso, al soñador, al iconoclasta de buenas intenciones, al hombre que, de cara a los intereses creados y a las situaciones estancadas, toca el repique clamoroso de las renovaciones.

Con sus particularidades sustantivas y técnicas, el teatro de Luis Araquistain se hace ampliamente acreedor a los honores del estudio y a los de la difusión. No es un teatro que merezca el olvido y el desprecio de nadie. Todo en él está atrayendo la alención del estudioso: todo en él está ofreciendo interés por la novedad de la doctrina y la amplitud ideológica, a la vez que por su vasta trascendencia y su avanzado atrevimienlo.

Incuestionablemente, el teatro de Luis Araquistain será siempre para públicos de determinada preparación intelectual, para públicos amigos del raciocinio y partidarios de la critica; para públicos que anhelan remover profundamente la estática social y abrir caminos nuevos en el terreno de la ética.

En lo que lleva elaborado. Araquistain ha dado ya la directriz que habrá de presidir su producción escénica y ha fijado la nota distintiva de sụs procedimientos. Lo que venga más tarde ha de seguir, sin duda. por el mismo derrotero. Será la suya una dramática de ideas; una dramática que habrá de hablar más al cerebro que a la sensibilidad: que hará pensar más que sentir: pero, en todo caso, merecedora, en la variedad de sus facetas, del estudio más prolijo.

Por lo ya realizado, podemos juzgar perfectamente la futura 
https://doi.org/10.29393/At5-339GMAT10339

Araquistain en el teatro

533

labor de Araquistain en el teatro: será labor maciza y fuerte; llena de nervio y de interés y en la cual, junto a la más exquisita y continuada dignidad literaria, arderán como llamas calcinantes, la rebeldia reformista y el afán de nuevas normas.

Traspasados los umbrales de la íniciación. corresponde a Araquistain entrar de lleno a la campiña del lealro. Se le esperan grandes triunfos y magnificos laureles.

GUILLERMO MUÑOZ MEDINA, 